\title{
Interactions among Florida sponges. I. Reef habitats
}

\author{
Sebastian Engel ${ }^{1,2}$, Joseph R. Pawlik ${ }^{1, *}$ \\ ${ }^{1}$ University of North Carolina at Wilmington, Center for Marine Science, 5600 Marvin K. Moss Lane, Wilmington, \\ North Carolina 28409, USA \\ ${ }^{2}$ Present address: Scripps Institution of Oceanography, La Jolla, California 92093, USA
}

\begin{abstract}
Spatial interference competition is well described for many sessile marine invertebrates, but few studies have addressed interactions between neighboring sponges. We conducted transect surveys to assess interspecific interactions among sponges in coral reef habitats in Key Largo, Florida, USA. In total, 15 transect sites were surveyed at 5 reef locations with mean densities ranging from $13.0 \pm 3.6$ to $33.3 \pm 5.9$ sponges $\mathrm{m}^{-2}$. The most abundant of over 43 sponge species observed were Amphimedon compressa, Aplysina cauliformis, Aplysina insularis, and Niphates erecta, while the least abundant were Hippospongia lachne, Ircinia campana, and Pseudaxinella lunaecharta. A nearest-neighbor technique was used to determine the degree and frequency of interactions between randomly selected sponge pairs. Overall, $40.4 \%$ of sponges occurred alone, $31.0 \%$ in proximity to, and $28.6 \%$ in contact with other sponge species. Among sponges in contact interactions, $18.7 \%$ were epibionts, $19.4 \%$ were basibionts, and a relationship could not be resolved for the remainder. Statistical analyses of the frequencies of each interaction category revealed that the ability to overgrow or resist overgrowth varied among species. For example, Aka coralliphagum, Ectyoplasia ferox, and Phorbas amaranthus occurred alone in $>60 \%$ of their interactions and were never overgrown by other species with which they came into contact. In contrast, Agelas schmidti, Ircinia felix, Dysidea janiae, and Scopalina ruetzleri occurred alone in $<30 \%$ of their interactions, with the first 2 species overgrown by, and the latter 2 overgrowing, most other species with which they came in contact. All contact interactions were further statistically examined, and 41 interspecific sponge pairs revealed significant overgrowth ability by 1 of the interacting species. While the overgrowth ability of a species is dependent on sponge morphology, the ability to resist overgrowth is associated with the production of allelochemicals.
\end{abstract}

KEY WORDS: Coral reef $\cdot$ Interspecific interactions $\cdot$ Nearest-neighbor $\cdot$ Overgrowth $\cdot$ Sponges $\cdot$ Allelopathy

\section{INTRODUCTION}

Competitive interactions among sessile marine invertebrates have been studied extensively in many hard-substratum environments such as rocky shores (e.g. Connell 1961, Dayton 1971, Sebens 1986) and coral reefs (e.g. Jackson 1977, Suchanek et al. 1983). In these habitats, space is thought to be the most important limiting resource, and spatial interference competition often results in the overgrowth of one species by another (Stebbing 1973, Quinn 1982,
Rubin 1985). On coral reefs, sponges are commonly described as competitively dominant over other sessile invertebrates in their ability to overgrow or resist overgrowth by neighboring organisms including bryozoans and corals (Jackson \& Buss 1975, Aerts 1998, Hill 1998). While competitive interactions among corals (Lang 1971, 1973, Sammarco et al. 1983, 1985, La Barre et al. 1986) and bryozoans (Buss 1979, Rubin 1985, Lopez Gappa 1989, Barnes \& Dick 2000) are well documented, relatively few studies have addressed spatial interference interactions among 
sponges (Rützler 1970, Sará 1970, Pansini \& Pronzato 1990, Wulff 1997).

Sponges are abundant and diverse members of benthic communities in coral reef habitats (Reiswig 1973, Rützler 1986, Diaz \& Rützler 2001, Alcolado et al. 2004). Despite their sessile lifestyle and a soft, fleshy tissue that lacks physical protection from predation (Chanas \& Pawlik 1995, 1996, Pawlik et al. 1995, Pawlik 1997), sponges are often found thriving on coral reefs that are characterized by high predation pressure (Huston 1985, Dunlap \& Pawlik 1996, 1998) and intense spatial interference competition (Jackson \& Buss 1975, Suchanek et al. 1983). While sponge-coral interactions are important to the community structure of Indo-Pacific reefs where coral cover is high (De Voogd et al. 2004), Caribbean reefs are dominated by sponges which attain much greater biomass per unit surface area than other sessile invertebrates (Reiswig 1973), and surpass corals in diversity and abundance (Suchanek et al. 1983, Targett \& Schmahl 1984, Diaz \& Rützler 2001, Alcolado et al. 2004). Further, studies have demonstrated that sponges are competitively dominant in interference interactions with corals (Suchanek et al. 1983, Porter \& Targett 1988, Vicente 1991). In Guam, nearly $1 \mathrm{~km}$ of coral reef was covered by a species of the genus Terpios (Bryan 1973). A long-term study investigating the competitive abilities of organisms settling on artificial substrata revealed that sponges rank superior to most other marine invertebrates such as bryozoans, barnacles, polychaetes, tubicolous amphipods, and hydroids (Russ 1982). Considering the well-recognized dominance of sponges over other sessile marine organisms, it is surprising that only a handful of studies have examined interspecific overgrowth interactions among sponges (Rützler 1970, Sará 1970, Pansini \& Pronzato 1990, Wulff 1997).

Interspecific sponge interactions are difficult to assess because it is often not clear whether interacting individuals are competing or mutualistic. Sponges have been described as competing for available substrata (Hartman 1957, Rützler 1965); however, tissue necrosis or mortality is rarely observed among overgrown individuals, suggesting mutualistic associations (Rützler 1970, Sará 1970). Further, some sponges can undergo specialized tissue adaptations to allow overgrowth by epibiotic species (Rützler 1970). Consequently, dense and diverse sponge populations are often vertically stratified and can remain stable over long periods of time (Sará 1970, Pansini \& Pronzato 1990). Mutualistic relationships have also been described among branching sponges (Wulff 1997). While these studies focused on mutualistic sponge associations, little is known about the extent to which competitive interactions shape the community structure of sponges on coral reefs.
The purpose of this study was to investigate spatial interference interactions among sponge species in coral reef habitats of the Florida Keys, USA. Transect surveys were conducted to determine local sponge demographics and examine interspecific interactions. In addition, a nearest-neighbor technique was used to assess the degree of interaction among individual sponge species and their ability to overgrow or resist overgrowth by neighboring sponges. Frequencies of observed sponge interactions were analyzed statistically and comparisons made among overgrowth ability, sponge morphology, and the allelopathic effects of sponge extracts (Engel \& Pawlik 2000).

\section{MATERIALS AND METHODS}

Study areas and sponge identification. Interspecific sponge interactions were examined on different coral reef habitats in Key Largo, Florida (Fig. 1a). Fifteen transect sites were established on the following 5 reefs, listed from north to south: 4 sites at North Dry Rocks $\left(25^{\circ} 07.85^{\prime} \mathrm{N}, 80^{\circ} 17.52^{\prime} \mathrm{W}\right) ; 3$ sites at Dixie Shoal

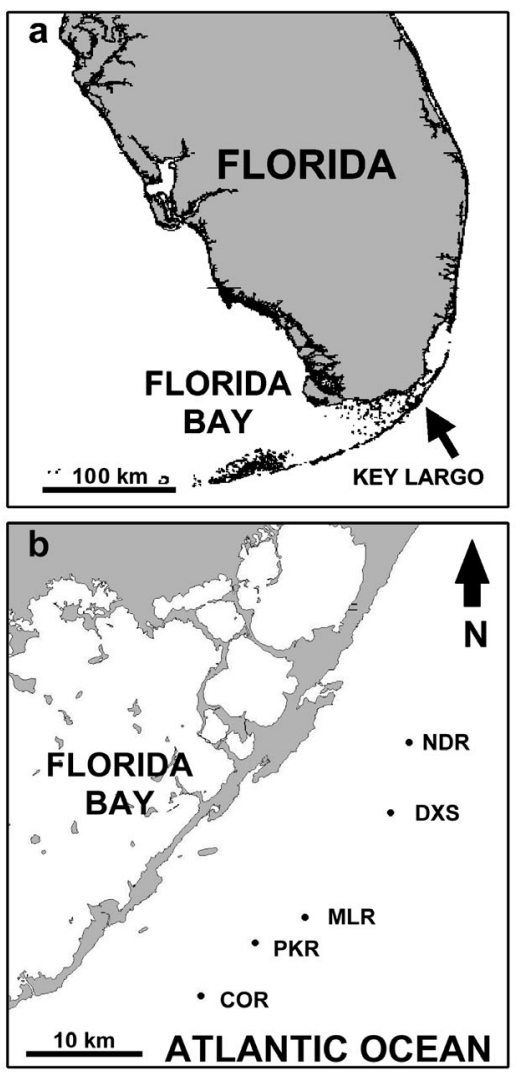

Fig. 1. Map of (a) Southern Florida indicating the location of Key Largo and (b) Key Largo indicating the location of the following 5 study locations: NDR = North Dry Rocks, DXS = Dixie Shoal, MLR = Molasses Reef, PKR = Pickles Reef, COR = Conch Reef 
$\left(25^{\circ} 04.66^{\prime} \mathrm{N}, 80^{\circ} 18.74^{\prime} \mathrm{W}\right) ; 3$ sites at Molasses Reef $\left(25^{\circ} 01.02^{\prime} \mathrm{N}, 80^{\circ} 22.53^{\prime} \mathrm{W}\right) ; 2$ sites at Pickles Reef $\left(24^{\circ} 59.07^{\prime} \mathrm{N}, 80^{\circ} 24.97^{\prime} \mathrm{W}\right) ; 3$ sites at Conch Reef $\left(24^{\circ} 57.01^{\prime} \mathrm{N}, 80^{\circ} 27.25^{\prime} \mathrm{W}\right.$ ) (Fig. 1b). Individual sites within a given reef location were variable with regard to water flow, temperature fluctuation, and light exposure. In addition to analyzing data for all reef sites, location-dependent factors were taken into consideration by analyzing data grouped by reef location.

The sponge communities at all reef locations are similar to those found throughout the Caribbean and contain most of the same species (Reiswig 1973, Alvarez et al. 1991, Diaz et al. 1991, Schmahl 1991, Van Soest 1994, Alcolado et al. 2004). All sponge individuals were identified by spicule and tissue preparations based on the available literature (DeLaubenfels 1936, Wiedenmayer 1977, Rützler 1986, Zea 1987, Hopper \& Van Soest 2002). Conforming to most previous assessments of sponge communities (references above), this study quantified sponge number rather than biomass or substratum coverage. As defined by Hartman \& Reiswig (1973), a sponge individual is contained within continuous tissue connected by an unbroken surface pinacoderm. Attached multiple lobes, tubes, or branches were considered part of the same individual.

Transects and nearest-neighbor analysis. Belt transects were conducted to determine the abundance and diversity of sponge species and examine interspecific interactions at different coral reef locations. Each transect was established by attaching a $10 \mathrm{~m}$ line, marked at $1 \mathrm{~m}$ intervals, to a randomly chosen point and stretching it parallel to the isobath of a chosen depth. A quadrat $\left(1 \mathrm{~m}^{2}\right)$ was placed directly over the transect line, with 2 opposing edges centered and perpendicular to the transect line. The quadrat was moved along the $1 \mathrm{~m}$ interval marks of the transect line 10 times, covering a total of $10 \mathrm{~m}^{2}$. Three $10 \mathrm{~m}^{2}$ transects were performed at each site, resulting in a total survey area of $30 \mathrm{~m}^{2}$ of benthos at each transect site.

In each quadrat, the total number of sponge individuals was recorded and each identified to species level. These data were used to determine species abundance and diversity at each of the 5 reef locations. In addition, a nearest-neighbor technique was used to assess the degree of interactions between randomly chosen sponge pairs (Brower et al. 1997). Focal sponges were randomly selected by dropping 4 plastic markers into the quadrat, and choosing the closest sponge to each marker. The nearest-neighbor of each focal sponge was identified and the distance between the 2 individuals measured. Distance measurements were conducted along the shortest line connecting the proximal edges of 2 neighboring sponge individuals. This procedure was repeated 4 times, making certain that neither the focal nor the nearest-neighbor sponges were selected twice for either category.

Observations of interacting sponge pairs were limited to those with a maximum distance of $5 \mathrm{~cm}$ between them. This limit was assigned under the assumption that the only interaction mechanism in non-contact encounters is the release of water-soluble allelochemicals with a maximum effective range of $5 \mathrm{~cm}$. This assumption is supported by Turon et al. (1996), who found that a strong non-random pattern of negative sponge associations diminished with increasing distance and was absent beyond $5 \mathrm{~cm}$ from the edge of the interacting sponge species. In addition, studies investigating interactions among corals and between sponges and corals have indicated that noncontact interactions may have an interactive range of up to $5 \mathrm{~cm}$ (Richardson et al. 1979, Sheppard 1981, Aerts \& Van Soest 1997, Aerts 1998). Given the above, we defined the following 3 categories of interactions:

Alone: includes encounters in which the focal sponge is found without a neighboring sponge growing within a $5 \mathrm{~cm}$ radial margin around its edge (distance to nearest-neighbor $>5 \mathrm{~cm}$ ).

Proximate: includes encounters in which the focal sponge is found next to a neighboring sponge within its $5 \mathrm{~cm}$ radial margin but does not come in direct contact with it.

Contact: includes encounters in which the focal sponge is in direct contact with its neighboring sponge (distance to nearest-neighbor $=0 \mathrm{~cm}$ ).

Statistical analyses were conducted on data for sponge species that occurred 5 or more times. A chisquare goodness of fit test $\left(\chi^{2} \times 5.991\right.$, df $\left.=2, p<0.05\right)$ was used to assess differences in frequencies between the above interaction categories for each sponge species. The null hypothesis $\left(H_{0}\right)$ tested assumed equal distribution of individuals occurring alone, in proximate, and contact interactions. Rejecting the $H_{0}$ led to further investigations to examine species aggregation patterns (Zar 1996).

All contact interactions were subject to further analysis. In each case the sponge individuals encountered in a contact interaction were classified into 1 of 3 categories defined by the following 3 possible outcomes:

Over: includes encounters in which the focal sponge occurs as the epibiont, overgrowing an individual of another species.

Under: includes encounters in which the focal sponge occurs as the basibiont, being overgrown by an individual of another species.

Equal: includes contact interactions in which the degree of overgrowth is not sufficient to distinguish between epi- and basibionts. Both interacting sponge individuals are classified as equal. 
Pairs of sponge species observed in 5 or more contact interactions were chosen for statistical analysis. The overgrowth ability of each sponge species was examined by calculating the average overgrowth rate from the observed frequencies of each contact category. This method was adapted from Russ (1982), who assigned points to interacting individuals to determine the competitive dominance of different marine invertebrates. For each observed contact interaction, 2 points were assigned to the overgrowing sponge and 0 points to the species being overgrown. For each observed 'equal' interaction, 1 point was given to both individuals. A chi-square goodness of fit test $\left(\chi^{2} \times 3.841, \mathrm{df}=1\right.$, $\mathrm{p}<0.05$ ) was conducted on the sums of these points as the observed values, and the total number of interactions (n) was used as the expected value for both species. The $H_{0}$ tested was that there was no difference in the overgrowth ability of the 2 interacting species. If the $H_{0}$ was rejected, the species with the higher overgrowth rate was regarded to be more likely to overgrow the other species and considered epibiotic.

The extent of the overgrowth of each sponge species observed in contact interactions was determined by calculating a species-specific overgrowth index using the results from the sponge pair analysis. The overgrowth index was calculated by subtracting the number of basibiotic interactions from the number of epibiotic interactions, and dividing by the total number of statistically tested pair interactions. This overgrowth index ranged from 1 to -1 , indicating a species that is always overgrowing other sponges to a species that is always being overgrown by other sponges, respectively.

\section{RESULTS}

\section{Sponge species abundance and diversity}

Overall, 9984 sponge individuals comprising 43 species were recorded at all reef locations (Table 1). Species richness was highest at Molasses Reef (41 species),

Table 1. Sponge abundance and diversity indices for all reef locations. Species with less than 5 individuals were not included. $S=$ species richness, $\mathrm{n}=$ total number of individuals, $l_{\mathrm{S}}=$ Simpson's dominance, $D_{\mathrm{S}}=$ Simpson's diversity, $E_{\mathrm{S}}=$ evenness, NDR $=$ North Dry Rocks, Dixie Shoal, MLR =

Molasses Reef, PKR $=$ Pickles Reef, $\mathrm{COR}=$ Conch Reef

\begin{tabular}{|lcccccc|}
\hline & Overall & NDR & DXS & MLR & PKR & CON \\
\hline$S$ & 43 & 35 & 31 & 41 & 31 & 40 \\
$\mathrm{n}$ & 9984 & 3273 & 1144 & 2491 & 925 & 2085 \\
$l_{\mathrm{S}}$ & 0.057 & 0.079 & 0.062 & 0.056 & 0.092 & 0.055 \\
$D_{\mathrm{S}}$ & 0.943 & 0.922 & 0.939 & 0.944 & 0.908 & 0.945 \\
$E_{\mathrm{S}}$ & 0.966 & 0.948 & 0.969 & 0.967 & 0.938 & 0.969 \\
\hline
\end{tabular}

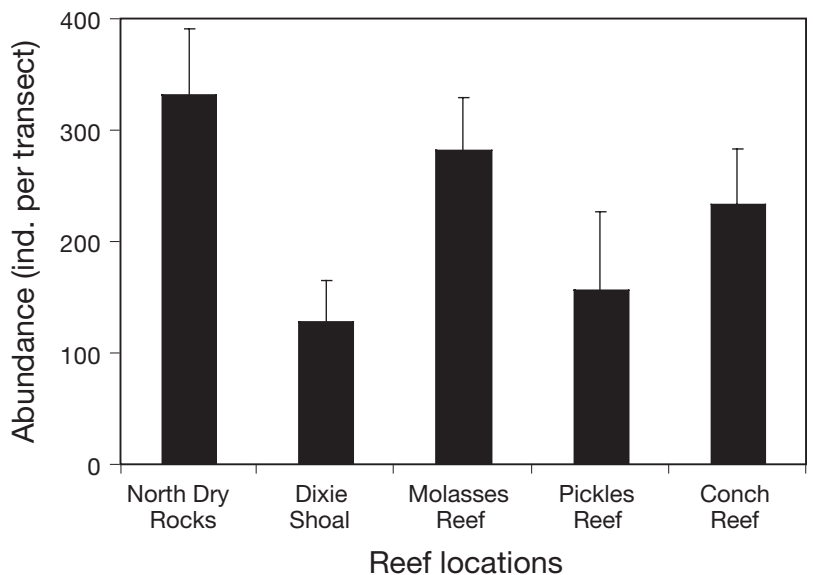

Fig. 2. Number of sponge individuals (mean $+\mathrm{SD}$ ) per transect for each reef location

and lowest at Dixie Shoal and Pickles Reef (31 species) (Table 1). Sponge abundance was greatest at North Dry Rocks with a total of 3273 sponges averaging $332.9 \pm 59.0$ ind. transect $^{-1}$, followed by Molasses Reef $(2491 ; 283.8 \pm 46.8)$, Conch Reef $(2085 ; 234.9 \pm 50.2)$, Dixie Shoal $(1144 ; 129.8 \pm 36.3)$, and Pickles Reef $(925$; $158.2 \pm 70.6)$ (Fig. 2, Table 1). Simpson's diversity indices indicated high species diversity at all reef locations, with the sponge community at Conch Reef being the most diverse and that of Pickles Reef the least diverse (Table 1). Morisita's indices revealed some differences in the sponge communities at each reef location, with the communities at Conch Reef and Molasses Reef being most similar, and those at Dixie Shoal and Pickles Reef most different (Table 2).

The most abundant sponge species were Amphimedon compressa and Niphates erecta, with over 1000 total individuals averaging over 200 individuals at each reef location (Fig. 3). The sponges Aplysina cauliformis, Aplysina insularis, and Scopalina ruetzleri were also relatively abundant, with over 500 total individuals averaging over 100 individuals at each reef location (Fig. 3). Third most abundant were Agelas schmidti, Callyspongia vaginalis, Ectyoplasia ferox, Iotrochota birotulata, Monanchora arbuscula, and Niphates digitalis, with over 300 total individuals averag-

Table 2. Morisita's index of community similarity between each reef location based on Simpson's dominance $\left(l_{\mathrm{S}}\right)$ (Table 1$)$; see Table 1 for reef abbreviations

\begin{tabular}{|lcccc|}
\hline Reef & NDR & DXS & MLR & PKR \\
\hline COR & 0.753 & 0.816 & 0.942 & 0.656 \\
PKR & 0.917 & 0.638 & 0.757 & \\
MLR & 0.891 & 0.769 & & \\
DXS & 0.641 & & & \\
\hline
\end{tabular}




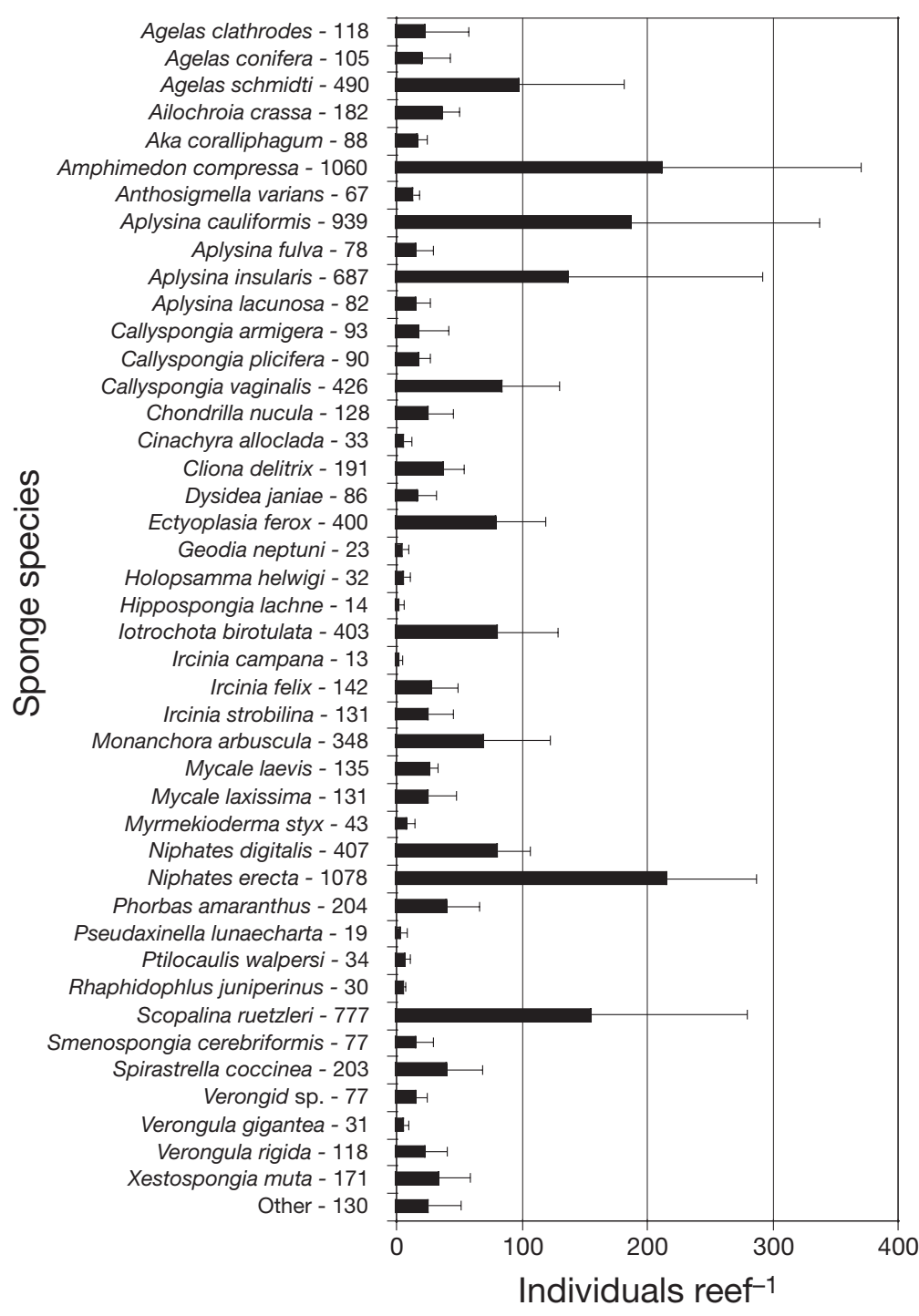

Fig. 3. Number of sponge individuals (mean + SD) per reef location for 43 most abundant species. Total number of individuals for each species is given next to the species name. 'Other' includes species with $<5$ ind.

ing over 50 individuals at each reef location (Fig. 3). The least abundant sponges were Hippospongia lachne, Ircinia campana, and Pseudaxinella lunaecharta, with less than 20 total individuals and only present at some but not all reef locations (Fig. 3).

\section{Interactions among sponge species}

Interspecific sponge interactions were examined with the nearest-neighbor data from a total of 5289 focal sponges recorded at all transect sites. Overall, $40.4 \%$ of focal sponges occurred alone, $31.0 \%$ in proximal, and $28.6 \%$ in contact interactions (Fig. 4a). The frequencies of these 3 interaction categories varied considerably among sponge species. The following species occurred alone more frequently than in proximity to or in contact with other sponge species: Aka coralliphagum, Anthosigmella varians, Aplysina insularis, Aplysina lacunosa, Cliona delitrix, Ectyoplasia ferox, Monanchora arbuscula, Mycale laevis, Phorbas amaranthus, Ptilocaulis walpersi, Rhaphidophlus juniperinus, Spirastrella coccinea, and an unknown species of the genus Verongula (Fig. 4a). Amphimedon compressa and Dysidea janiae occurred most frequently in proximal interactions, and Agelas schmidti, Callyspongia armigera, Iotrochota birotulata, and Scopalina ruetzleri were observed more frequently in contact interactions than in proximal interactions or alone (Fig. 4a).

Among all 1512 sponge individuals observed in contact interactions, $61.9 \%$ occurred in 'equal' interactions, while only $18.7 \%$ were encountered as epibionts and $19.4 \%$ as basibionts to other sponge species (Fig. 4b). Overall, 86\% of all species encountered in contact interactions occurred more frequently in 'equal' interactions than in those resulting in overgrowth (Fig. 4b). Because of the high frequency of 'equal' interactions between most sponges, the average overgrowth ability for each of the 29 species encountered in contact interactions was examined by conducting a chi-square goodness of fit test on assigned points $\left(\chi^{2} \times 3.841\right.$, $\mathrm{df}=1$, $\mathrm{p}<0.05)$. While Dysidea janiae and Scopalina ruetzleri overgrew other species most frequently, Agelas schmidti and Ircinia felix were overgrown by other species most frequently (Fig. 4b).

Given that the percentages of each category are derived from the total number of observations, they can be regarded as the average frequencies for each interaction category. Most sponge species displayed frequencies close to the average frequencies of each category (Fig. 5). However, a few species displayed frequencies well above or below the average frequency of a given category. For example, Aka coralliphagum, Cliona delitrix, Mycale laevis, and Ectyoplasia ferox occurred alone in $>65 \%$ and in contact in $<10 \%$, of all interactions (Figs. 4a \& 5b). In contrast, Agelas schmidti, Callyspongia armigera, and Iotrochota birotulata occurred alone in $<25 \%$ and in contact in $>55 \%$ of all interactions (Figs. $4 \mathrm{a} \& 5 \mathrm{a}$ ). Among those species encountered in contact interactions, 

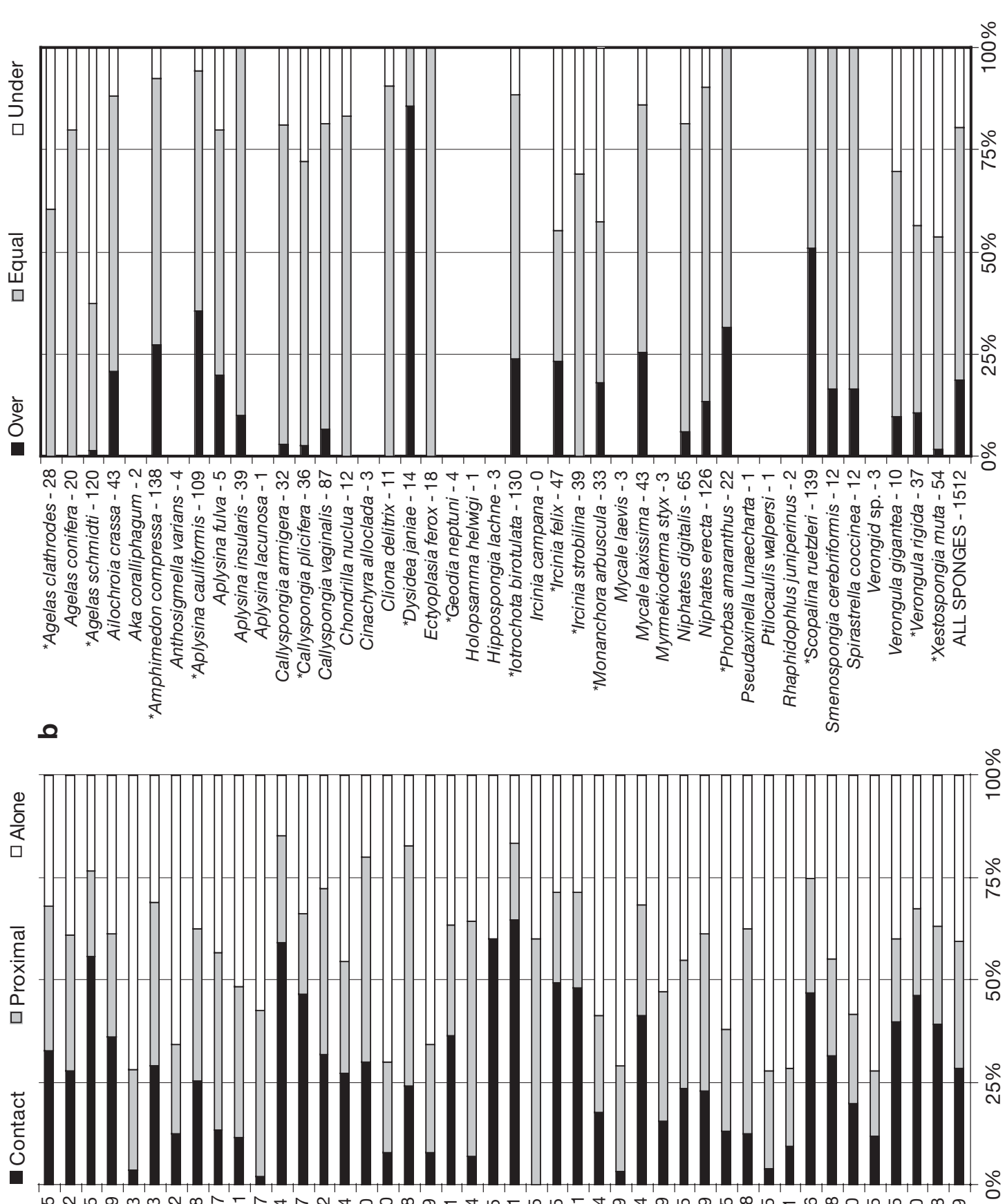

웅

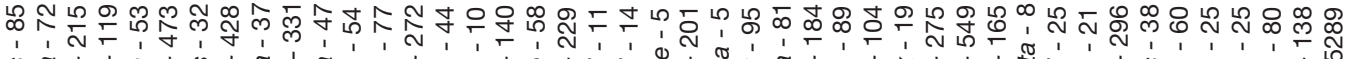

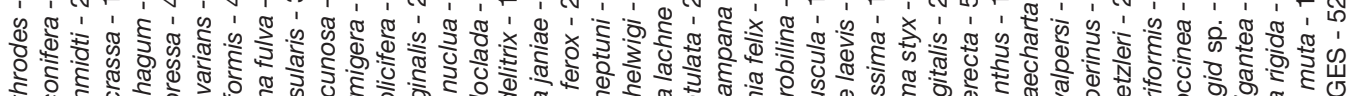

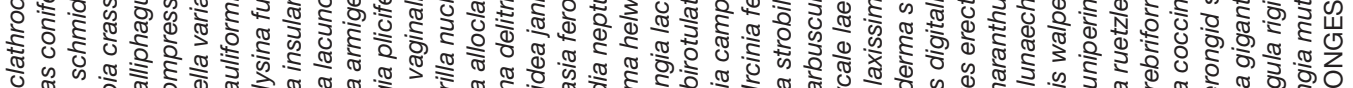

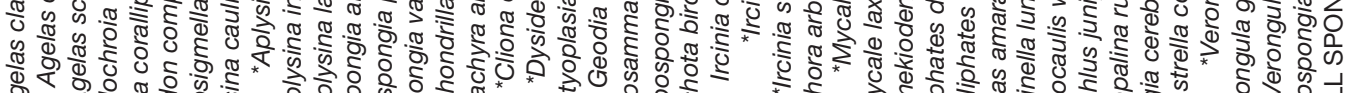

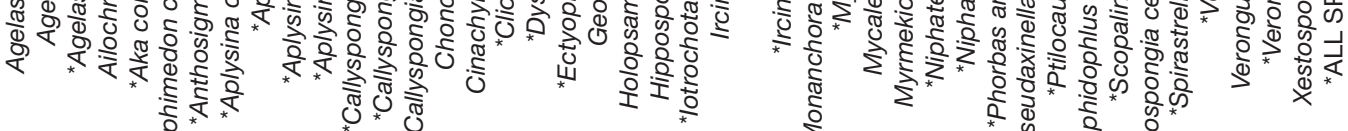

(ర

sə!̣əds əбuods

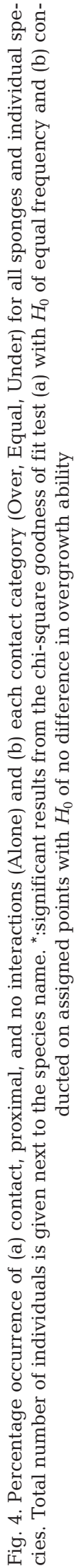




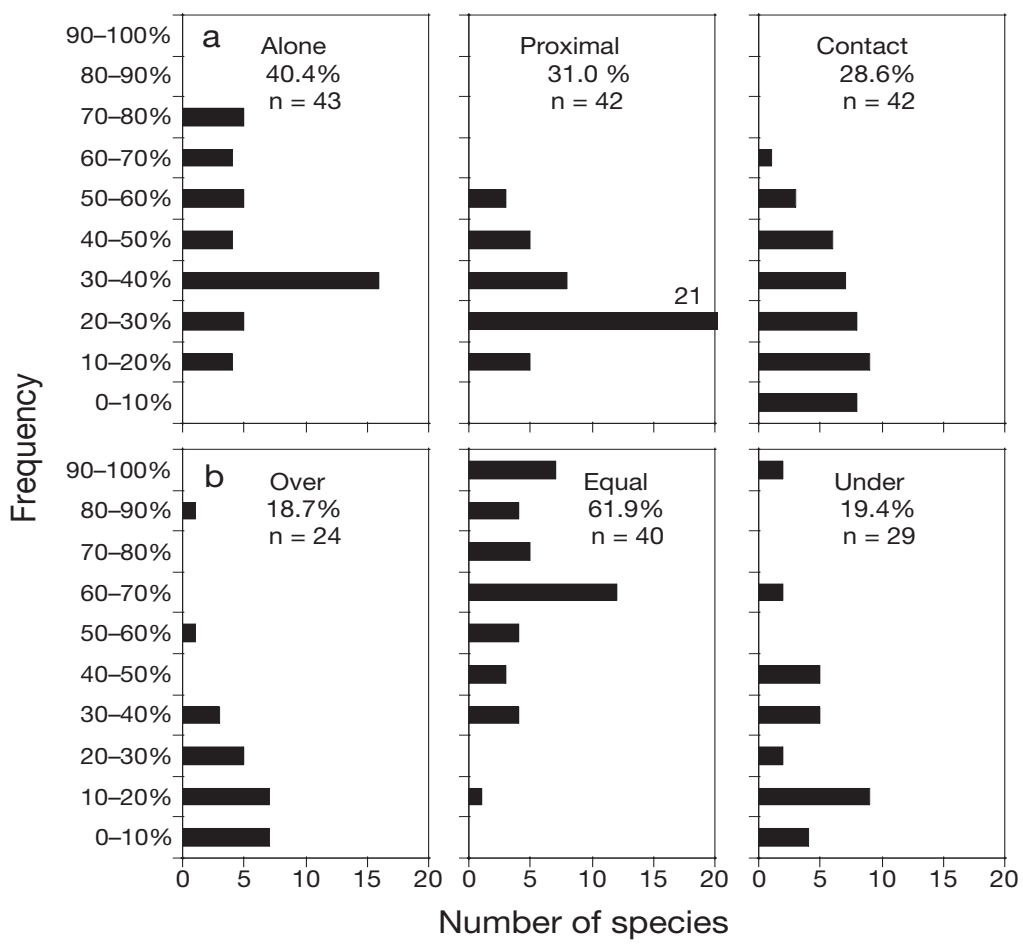

Fig. 5. (a) Frequencies of each interaction category and (b) each contact category displayed by the number of reef species encountered in each category. Frequency data were pooled in increments of $10 \%$. Overall percentage occurrence and total number of species (n) for each category is given

Dysidea janiae overgrew other species in $>85 \%$, while Agelas schmidti was overgrown by other species in $>50 \%$ of all contact interactions (Figs. $4 \mathrm{~b} \& 5 \mathrm{~b}$ ).

The overgrowth ability for the 21 most abundant species occurring in contact interactions was further examined by statistically analyzing the frequencies of contact categories between each species pair. The chisquare test results for each interacting sponge pair are presented in a matrix of interspecific contact interactions along with the calculated overgrowth index for each species (Fig. 6). Dysidea janiea, Phorbas amaranthus, and Scopalina ruetzleri were the only species with an overgrowth index of 0.5 or greater because they were rarely overgrown and frequently overgrew species with which they came into contact (Fig. 6). Ailochroia crassa was also rarely overgrown; however, its overgrowth index of 0.4 reflects a relative increase in 'equal' interactions (Fig. 6). Positive overgrowth indices were also observed for Amphimedon compressa, Aplysina cauliformis, Iotrochota birotulata, and Niphates erecta (Fig. 6). Mycale laxissima was the only species with an overgrowth index of 0 because it was equally likely to overgrow and be overgrown by other sponge species (Fig. 6). The remaining sponge species surveyed in this study had negative overgrowth indices because they were most frequently overgrown by sponges with which they came into contact (Fig. 6).

All sponge species were grouped into 7 categories defined by distinct morphological growth characteristics (Jackson 1979, BouryEsnault \& Rützler 1997) (Table 3). Overall, $39.5 \%$ of all species were lobate, $20.9 \%$ were branching, $11.6 \%$ were encrusting, $9.3 \%$ were globular, $7 \%$ were tubular, $7 \%$ were barrel shaped, and $4.7 \%$ were turbinate (Table 3 ). The average overgrowth index of each species in each category was used to assess the overgrowth ability of each morphological growth form (Fig. 7). The only encrusting sponge observed in contact interactions was Scopalina ruetzleri, which was epibiotic on 9 of the 13 species with which it interacted (Fig. 6), and ranked at the top of the overgrowth hierarchy with and overgrowth index of 0.69 (Fig. 7). The branching sponges observed in contact interactions included Amphimedon compressa, Aplysina cauliformis, Iotrochota birotulata, and Niphates erecta (Table 3); these sponges had an average overgrowth index of 0.25 , overgrowing most sponges in the other categories except for the encrusting sponge $S$. ruetzleri, and the lobate sponges Dysidae janiae and Phorbas amaranthus (Figs. 6 \& 7). Lobate sponges comprised the largest group of morphologically similar species occurring in contact interactions (Table 3 ). The average overgrowth index of all lobate species was 0.07 , reflecting clear differences in the overgrowth ability of lobate species over branching or globular sponge species (Fig. 7). All tubular and turbinate sponges averaged a combined overgrowth index of -0.25 because they were frequently overgrown by encrusting and branching sponges and only in some cases were found growing on globular and barrel sponges (Figs. $6 \&$ 7). No significant overgrowth ability was observed between lobate, tubular, or turbinate sponges. Globular and barrel sponges ranked lowest in the overgrowth hierarchy, with average overgrowth indices of -0.5 and -0.54 , respectively (Figs. 6 \& 7). The globular sponges Ircinia felix and Ircinia strobilina and the barrel sponges Verongula gigantea and Xestospongia muta were frequently overgrown by encrusting, branching, tubular, and turbinate sponges (Fig. 7).

\section{DISCUSSION}

The competitive dominance of sponges over other sessile marine invertebrates is well documented (e.g. Jackson \& Buss 1975, Jackson 1977, Russ 1982, 


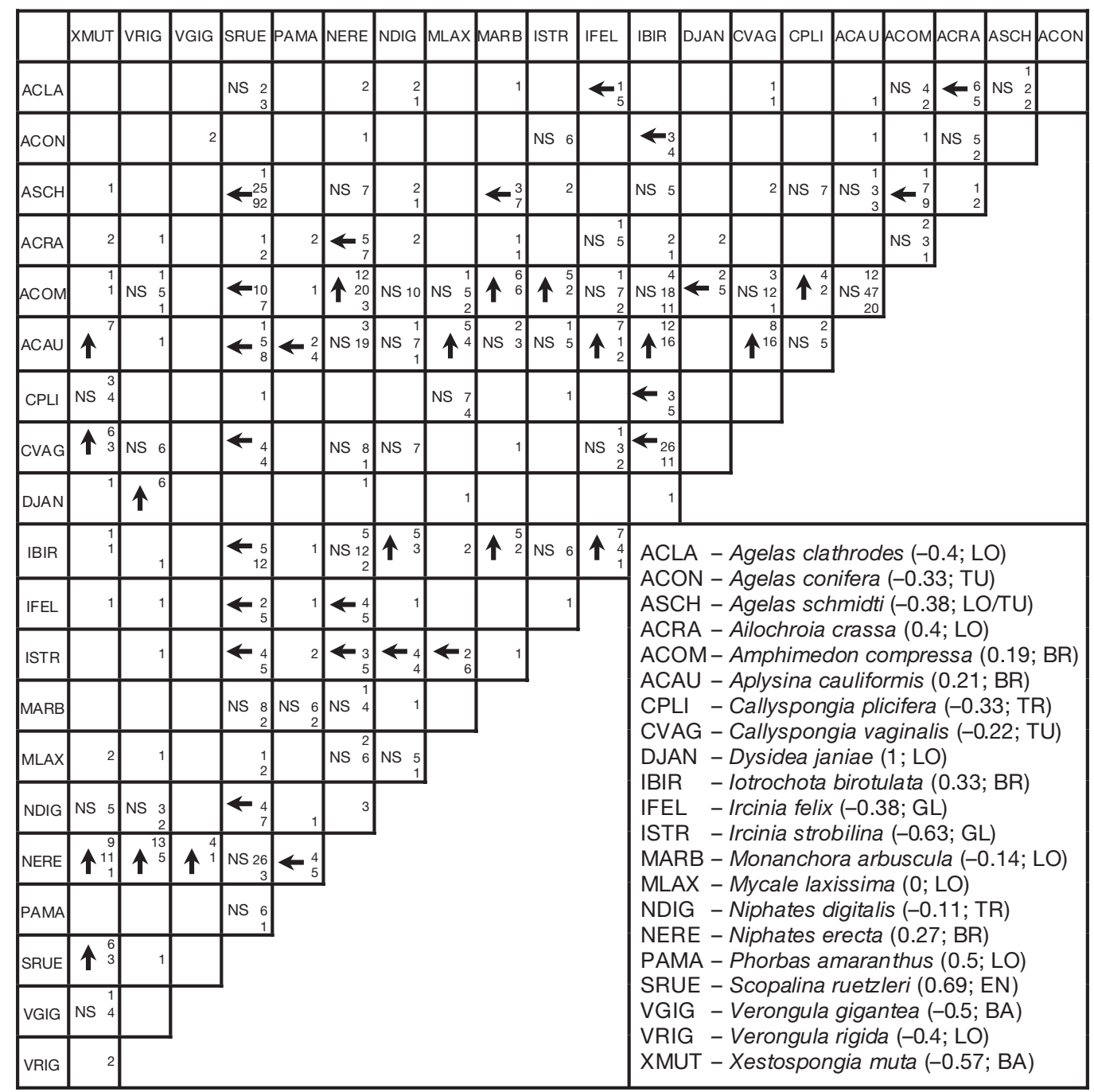

Fig. 6. Matrix of interspecific contact interactions for 21 sponge species occurring in overgrowth interactions 5 or more times. Each cell in the matrix represents the interactions between a pair of sponge species. The top number in each cell represents the total number of occurrences in which the species in the vertical column is observed overgrowing the species in the horizontal column. Middle numbers represent the number of equal occurrences. Bottom numbers represent the total number of occurrences in which the species in the vertical column is observed to be overgrown by the species in the horizontal column. Arrows represent results from the chi-square goodness of fit test, and point to the species that is more likely to be overgrown by the other. Blank cells did not have enough interactions to be considered for statistical analysis. Overgrowth index and morphology of each sponge species are given in parentheses next to the species name. NS = no significant overgrowth ability, EN $=$ encrusting, LO = lobate, $\mathrm{GL}=$ globular, $\mathrm{TU}=$ tubular, $\mathrm{TR}=$ turbinate, $\mathrm{BR}=$ branching, $\mathrm{BA}=$ barrel (see Table 3 )

Suchanek et al. 1983, Aerts 1998, Hill 1998); however, not much is known about interference interactions among sponge species. To date, most studies investigating interspecific interactions among sponges have only focused on mutualistic associations (Rützler 1970, Sará 1970, Pansini \& Pronzato 1990, Wulff 1997). The relatively stable and non-transitive nature of most sponge interactions often makes it difficult to identify epi- from basibiotic species (Rützler 1970, Sará 1970, Pansini \& Pronzato 1990). This difficulty was mirrored in our study, where over $86 \%$ of all sponge species in contact interactions occurred in 'equal' rather than clear overgrowth interactions (Figs. 4b \& 5b). However, our large sample size among diverse sponge populations (Tables 1 \& 2) allowed us to examine the remaining contact interactions that resulted in the overgrowth of one species by another.

The majority of sponge species were encountered alone or in close proximity to one another (Fig. 4a). Only $28.6 \%$ of all sponge individuals were observed in direct contact with other species (Fig. 4a), limiting our analysis of interspecific contact interactions to 
Table 3. Percentage occurrence of the 7 basic sponge morphologies in Key Largo, Florida. Morphological growth characteristics and descriptions modified from Jackson (1979)

\begin{tabular}{|lll|}
\hline Growth form & Description & Examples \\
\hline $\begin{array}{l}\text { Encrusting (EN) } \\
(11.6 \%)\end{array}$ & Flat, 2-dimensional encrustations & Aka coralliphagum \\
& Lateral growth only & Cliona deletrix \\
Lobate (LO) & Completely attached to substratum & Scopalina ruetzleri \\
$(39.5 \%)$ & Irregular encrustations & Ailochroia crassa \\
& Lateral and vertical growth & Dysidea janiae \\
& Most basal area is attached & Mycale laxissima \\
Globular (GL) & & Verongula rigida \\
$(9.3 \%)$ & Regular encrustations & Geodia neptuni \\
& Lateral and vertical growth & Ircinia felix \\
Tubular (TU) & Most basal area is attached & Ircinia strobilina \\
$(7.0 \%)$ & Regular or irregular branching tubes & Agelas conifera \\
Turbinate (TR) & Vertical and minimal lateral growth & Aplysina lacunosa \\
$(4.7 \%)$ & One restricted zone of basal attachment & Callyspongia vaginalis \\
Branching (BR) & Erect vase forms & Callyspongia plicifera \\
$(20.9 \%)$ & Vertical and minimal lateral growth & Cribrochalina vasculum \\
& One restricted zone of basal attachment & Niphates digitalis \\
Barrel (BA) & Linear or branching forms & Amphimedon compressa \\
$(7.0 \%)$ & Vertical and lateral growth & Aplysina cauliformis \\
& One or multiple restricted zones of basal attachment & Iotrochota birotulata \\
& & Niphates erecta \\
\end{tabular}

21 of the 43 species surveyed in this study. Of 210 possible interaction pairs among 21 species, only 81 species pairs interacted frequently enough to be considered for statistical analysis (Fig. 6). Of all statisti-

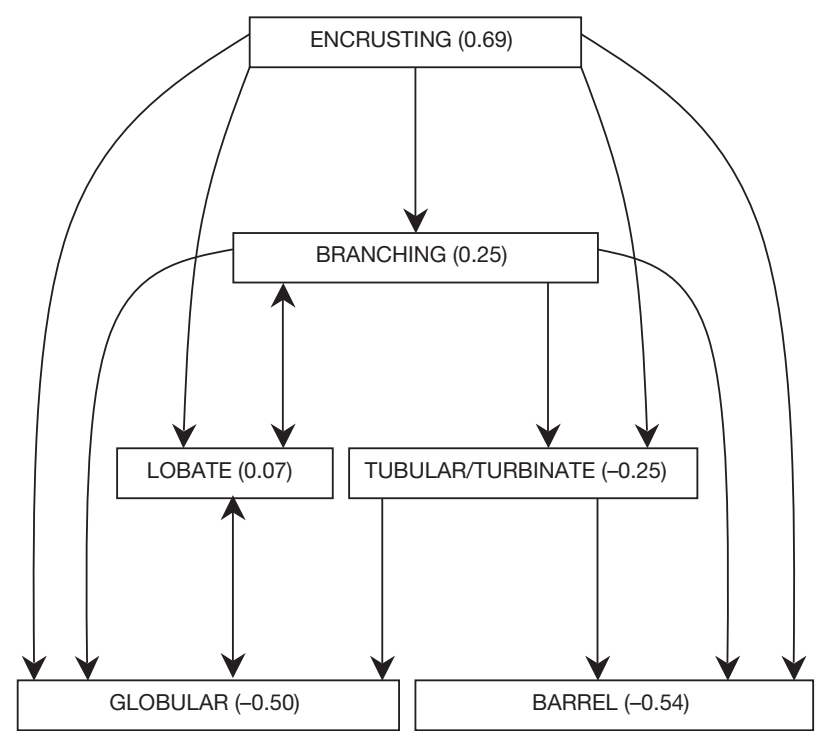

Fig. 7. Overgrowth ability for each morphological growth category defined in Table 3. Average overgrowth indices of all species in each category are given in parentheses. Arrows point from categories that are likely to overgrow to categories that are likely to be overgrown cally tested interaction pairs, 41 resulted in overgrowth by 1 of the interacting species (Fig. 6). While sponge morphology was a good indicator of the overgrowth ability of some species (Fig. 7), several interactions could not be explained by morphological differences alone. In these cases, sponges in contact interactions appeared to resist overgrowth by other species through the production of allelochemicals (Engel \& Pawlik 2000).

The top of the overgrowth hierarchy was occupied by Dysidea janiae, Phorbas amaranthus, and Scopalina ruetzleri, which were never observed to be overgrown by other species. Among these 3 species, $S$. ruetzleri was the most abundant (Fig. 3) and interacted with more species than either $D$. janiae or $P$. amaranthus (Fig. 6). The tissue of $S$. ruetzleri is delicate and thinly encrusts the substratum, including many other sponge species. The overgrowth ability of $S$. ruetzleri is likely a result of its ability to laterally overgrow available substrata, and the apparent inability of other sponges to overgrow such delicate tissue. In contrast, D. janiae and $P$. amaranthus have a lobate growth form, which does not lend itself to lateral overgrowth as readily as an encrusting growth form. Instead, the overgrowth ability of $D$. janiae and $P$. amaranthus appears to be mediated by allelochemicals that prevent overgrowth by other sponges. In a previous study investigating allelopathic interactions 
among sponges, extracts from $P$. amaranthus inhibited the lateral overgrowth of 3 other species (Engel \& Pawlik 2000). While extracts of $D$. janiae were not tested in this study, extracts of the related sponge Dysidea etheria also inhibited the overgrowth of the same 3 sponge species (Engel \& Pawlik 2000). In addition, a study conducted by Thacker et al. (1998) demonstrated that a sponge of the genus Dysidea produces a secondary metabolite that causes tissue necrosis in field assays which therefore facilitates its ability to overgrow other species.

The sponges Niphates erecta, Amphimedon compressa, Iotrochota birotulata, and Aplysina cauliformis all have a branching growth form that provides a good mechanism for escaping overgrowth by others 'in height' (Meesters et al. 1996). These species were among the most abundant (Fig. 3) and occurred in more contact interactions than any other sponge species (Fig. 6). Overgrowth by these sponges was usually the result of branches attaching to the side of other species and subsequently 'wrapping' around or 'creeping' up and over them (Wulff 1979, 1997). Both A. cauliformis and I. birotulata were often observed wrapping around the tubular sponge Callyspongia vaginalis, and the turbinate sponges Callyspongia plicifera and Niphates digitalis (Fig. 6). In contrast, $N$. erecta is usually found 'creeping' over lobate sponges such as Ailochroia crassa and Verongula rigida as well as both globular sponges Ircinia felix and I. strobilina (Fig. 6). Niphates erecta was also observed 'creeping' up larger sponges such as the barrel sponges Verongula gigantea and Xestospongia muta (Fig. 6). Interestingly, both $N$. erecta and I. birotulata were frequently overgrown by $A$. compressa and $A$. cauliformis, respectively (Fig. 6). Further, the extracts from A. compressa and A. cauliformis inhibited overgrowth by other sponge species; however, extracts from $N$. erecta and $I$. birotulata did not have allelopathic effects on sponge growth (Engel \& Pawlik 2000). While morphology enhanced the overgrowth ability of some branching sponges, the production of allelopathic metabolites appears to play an important role in preventing overgrowth by other, morphologically similar, species.

Lobate, tubular, and turbinate sponges did not rank high in their ability to overgrow other species (Fig. 7). In only 2 cases were tubular or turbinate sponges observed to overgrow other sponges: tubular Callyspongia vaginalis was observed growing on the giant barrel sponge Xestospongia muta, and turbinate $\mathrm{Ni}$ phates digitalis was observed growing on the globular sponge Ircinia strobilina (Fig. 6). In both cases it is clear that overgrowth did not occur via the lateral growth of sponge tissue; rather, the sponges were observed growing on top of the other species. Similar cases were observed with the sponge Ircinia felix growing on the surface of Agelas clathrodes (Fig. 6). These overgrowth interactions are most likely a result of larval settlement or the secondary attachment of the epibiont sponge on the basibiont. In all cases, globular and barrel sponges were likely to be overgrown by all other species with which they came into contact (Figs. 6 \& 7).

The sponges Aka coralliphagum, Cliona delitrix, Mycale laevis, and Ectyoplasia ferox were observed to occur alone more frequently than in proximity to or in direct contact with other sponge species (Fig. 4a). C. delitrix and A. coralliphagum are boring and burrowing sponges, respectively, and are usually found growing in coral mounds and ledges. While the sponge M. laevis is not classified as a boring sponge, it has strong similarities to both $C$. delitrix and $A$. coralliphagum in that it is usually found growing among the branches of many different coral species. All 3 species are often described as occurring in contact with different coral species (Aerts 1998). The sponge $E$. ferox is a low-growing and lobate species known to produce triterpene glycosides that prevent overgrowth by other species (Engel \& Pawlik 2000, Kubanek et al. 2002). Because of the low frequency of contact interactions, it is hard to assess the overgrowth ability of $E$. ferox with other sponges. However, given the abundance of E. ferox (Fig. 3), the probability of interspecific interactions is high. Therefore, the ability of E. ferox to prevent overgrowth appears to be mediated by the production of allelochemicals.

In conclusion, interference interactions among reef sponges frequently resulted in encounters in which it was not possible to distinguish the epi- from the basibiotic species. However, interspecific overgrowth interactions revealed 2 trends in the overgrowth ability of a species: (1) sponge morphology provided a good indicator of the overgrowth ability of some species, and (2) the production of allelochemicals appears to play an important role in preventing overgrowth by others.

Acknowledgements. This study was funded by grants from the NOAA/National Undersea Research Program (UNCW9523, 9812) and from the Biological Oceanography Program of the National Science Foundation (OCE-9711255, 0095724). Permits to perform this research were provided by the NOAA/Florida Keys National Marine Sanctuary and the State of Florida. We thank Greg McFall and the staff of NOAA/NURC in Key Largo, Florida, for logistical support. Special thanks to Robyn M. Palmer for her daily assistance with the collection of transect data. This research benefited from the advice of Timothy P. Henkel regarding data interpretation and presentation. We also thank William G. O'Neal for his assistance in the field. Dedicated to the memory of Sophie. 


\section{LITERATURE CITED}

Aerts LAM (1998) Sponge/coral interactions in Caribbean reefs: analysis of overgrowth patterns in relation to species identity and cover. Mar Ecol Prog Ser 175:241-249

Aerts LAM, Van Soest RWM (1997) Quantification of sponge/ coral interactions in a physically stressed reef community, NE Colombia. Mar Ecol Prog Ser 148:125-134

Alcolado PM, Grovas-Hernandez A, Marcos Z (2004) General comments on species inventory, fisheries, culture and some community features of the Porifera in Cuba. Boll Mus Ist Biol Univ Genova 68:175-186

Alvarez B, Diaz MC, Laughlin RA (1991) The sponge fauna on a fringing coral reef in Venezuela. I: Composition, distribution, and abundance. In: Rützler K (ed) New perspectives in sponge biology. Smithsonian Institution Press, Washington, DC, p 358-366

Barnes DKA, Dick MH (2000) Overgrowth competition in encrusting bryozoan assemblages of the intertidal and infralittoral zones of Alaska. Mar Biol 136:813-822

Boury-Esnault N, Rützler K (1997) Thesaurus of sponge morphology. Smithsonian Institution Press, Washingtion, DC, p 4-7

Brower JE, Zar JH, von Ende CN (1997) Field and laboratory methods for general ecology. Wm. C. Brown Publishers, Dubuque, IO

Bryan PG (1973) Growth rate, toxicity, and distribution of the encrusting sponge Terpios sp. (Hadromerida: Suberitidae) in Guam, Mariana Islands. Micronesica 9:237-242

Buss LW (1979) Bryozoan overgrowth interactions - the interdependence of competition for space and food. Nature 281:475-477

Chanas B, Pawlik JR (1995) Defenses of Caribbean sponges against predatory reef fish. II. Spicules, tissue toughness, and nutritional quality. Mar Ecol Prog Ser 127:195-211

Chanas B, Pawlik JR (1996) Does the skeleton of a sponge provide a defense against predatory reef fish? Oecologia 107:225-231

Connell JH (1961) The influence of interspecific competition and other factors on the distribution of the barnacle, Chthamalus stellatus. Ecology 42:710-723

Dayton PK (1971) Competition, disturbance, and community organization: the provision and subsequent utilization of space in a rocky intertidal community. Ecol Monogr 41: 351-389

DeLaubenfels MW (1936) A discussion of the sponge fauna of the Dry Tortugas in particular, and the West Indies in general, with material for a revision of the families and orders of the Porifera. Papers Tortugas Lab 30, Carnegie Inst Wash Publ 467

De Voogd N, Becking LE, Hoeksema BW, Noor A, Van Soest RWM (2004) Sponge interactions with spatial competitors in the Spermonde Archipelago. Boll Mus Ist Biol Univ Genova 68:253-261

Diaz MC, Rützler K (2001) Sponges: an essential component of Caribbean coral reefs. Bull Mar Sci 69:535-546

Diaz MC, Alvarez B, Laughlin RA (1991) The sponge fauna on a fringing coral reef in Venezuela. II: Community structure. In: Rützler K (ed) New perspectives in sponge biology. Smithsonian Institution Press, Washington, DC, p 367-375

Dunlap M, Pawlik JR (1996) Video-monitored predation by Caribbean reef fishes on an array of mangrove and reef sponges. Mar Biol 126:117-123

Dunlap M, Pawlik JR (1998) Spongivory by parrotfish in Florida mangrove and reef habitats. PSZN I: Mar Ecol 19: $325-337$
Engel S, Pawlik JR (2000) Allelopathic activities of sponge extracts. Mar Ecol Prog Ser 207:273-281

Hartman WD (1957) Ecological niche differentiatioin in the boring sponges (Clionidae). Evolution 11:291-297

Hartman WD, Reiswig HN (1973) The individuality of sponges. In: Boardman RS, Cheetham AH, Oliver WA (eds) Animal colonies. Dowden, Hutchinson \& Ross, Stroudsburg, PA, p 567-584

Hill M (1998) Spongivory on Caribbean reefs releases corals from competition with sponges. Oecologia 117:143-150

Hopper JMA, Van Soest RWM (2002) Systema Porifera: a guide to the classification of sponges. Kluwer Academic/ Plenum, New York

Huston MA (1985) Patterns of species diversity on coral reefs. Annu Rev Ecol Syst 16:149-177

Jackson JBC (1977) Competition on marine hard substrata. The adaptive significance of solitary and colonial strategies. Am Nat 111:743-767

Jackson JBC (1979) Morphological strategies of sessile animals. In: Larwood G, Rosen B (eds) Biology and systematics of colonial organisms. Academic Press, London, p 499-555

Jackson JBC, Buss L (1975) Allelopathy and spatial competition among coral reef invertebrates. Proc Natl Acad Sci USA 72:5160-5163

Kubanek J, Whalen KE, Engel S, Kelly SR, Henkel TP, Pawlik JR (2002) Multiple defensive roles for triterpene glycosides from two Caribbean sponges. Oecologia 131: 125-136

La Barre S, Coll JC, Sammarco PW (1986) Competitive strategies of soft corals (Coelenterata: Octocorallia). III. Aggressive and spacing interactions between alcyonarians. Mar Ecol Prog Ser 28:147-156

Lang J (1971) Interspecific aggression by scleractian corals. 1. The rediscovery of Scolymia cubensis. Milne Edwards \& Haime. Bull Mar Sci 21:952-959

Lang J (1973) Interspecific aggression by scleractian corals. 2. Why the race is not only to the swift. Bull Mar Sci 23: 260-279

Lopez Gappa JJ (1989) Overgrowth competition in an assemblage of encrusting bryozoans settled on artificial substrata. Mar Ecol Prog Ser 51:121-130

Meesters EH, Wesseling I, Bak RPM (1996) Partial mortality in three species of reef-building corals and the relation with colony morphology. Bull Mar Sci 58:838-852

Pansini M, Pronzato R (1990) Observations on the dynamics of a mediterranean sponge community. In: Rützler K (ed) New perspectives in sponge biology. Smithsonian Institution Press, Washington, DC, p 404-415

Pawlik JR (1997) Fish predation on Caribbean reef sponges: an emerging perspective of chemical defenses. Proc 8th Int Coral Reef Symp 2:1255-1258

Pawlik JR, Chanas B, Toonen RJ, Fenical W (1995) Defenses of Caribbean sponges against predatory reef fish. I. Chemical deterrency. Mar Ecol Prog Ser 127:183-194

Porter JW, Targett NM (1988) Allelochemical interactions between sponges and corals. Biol Bull (Woods Hole) 175: 230-239

Quinn JF (1982) Competitive hierarchies in marine benthic communities. Oecologia 54:129-135

Reiswig HM (1973) Population dynamics of three Jamaican Demospongiae. Bull Mar Sci 23:191-226

Richardson CA, Dustan P, Lang JC (1979) Maintenance of living space by sweeper tentacles of Montastrea cavernosa, a Caribbean reef coral. Mar Biol 55:181-186

Rubin JA (1985) Mortality and avoidance of competitive overgrowth in encrusting Bryozoa. Mar Ecol Prog Ser 23: 291-299 
Russ GR (1982) Overgrowth in a marine epifaunal community: competative hierarchies and competitive networks. Oecologia 53:12-19

Rützler K (1965) Systematik und Ökologie der Poriferen aus Nordadria. Z Morphol Oekol Tiere 55:1-82

Rützler K (1970) Spatial competition among Porifera: solution by epizoism. Oecologia 5:85-95

Rützler K (1986) Phylum Porifera (sponges). In: Sterrer W (ed) Marine fauna and flora of Bermuda. John Wiley \& Sons, New York, p 111-127

Sammarco PW, Coll JC, La Barre S, Willis B (1983) Competitive strategies of soft corals (Coelenterata: Octocorallia): allelopathic effects on selected Scleractinian corals. Coral Reefs 1:173-178

Sammarco PW, Coll JC, La Barre S (1985) Competitive strategies of soft corals (Coelenterata: Octocorallia). II. Variable defensive responses and susceptibility to scleractinian corals. J Exp Mar Biol Ecol 91:199-215

Sará M (1970) Competition and cooperation in sponge populations. Symp Zool Soc Lond 25:273-284

Schmahl GP (1991) Community structure and ecology of sponges associated with four southern Florida coral reefs. In: Rützler K (ed) New perspectives in sponge biology. Smithsonian Institution Press, Washington, DC, p 376-383

Sebens KP (1986) Spatial relationships among encrusting marine organisms in the New England subtidal zone. Ecol Monogr 56:73-96

Sheppard CRC (1981) Reach of aggressively interacting corals, and relative importance of interactions at different depths. Proc 4th Int Coral Reef Symp 2:363-368

Stebbing ARD (1973) Observations on colony overgrowth and spatial competition. In: Larwood GP (ed) Living and fossil Bryozoa. Academic Press, London, p 173-183

Editorial responsibility: Otto Kinne (Editor-in-Chief), Oldendorf/Luhe, Germany
Suchanek TH, Carpenter RC, Witman JD, Harvell CD (1983) Sponges as important space competitors in deep Caribbean coral communities. In: Reaka ML (ed) The ecology of deep and shallow coral reefs. Symposia series for Undersea Research 1. NOAA/NURP, Rockville, MD, p 55-61

Targett NM, Schmal GP (1984) Chemical ecology and distribution of sponges in the Salt River Canyon, St. Croix, USVI. NOAA Tech Mem OAR NURP-1, Rockville, MD

Thacker RW, Becerro MA, Lumbang WA, Paul VJ (1998) Allelopathic interactions between sponges on a tropical reef. Ecology 79:1740-1750

Turon X, Becerro MA, Uriz MJ, Llopis J (1996) Small-scale association measures in epibenthic communities as a clue for allelochemical interactions. Oecologia 108:351-360

Van Soest RWM (1994) Demosponge distribution patterns. In: Van Soest RWM, van Kempen TMG, Braekman JC (eds) Sponges in time and space. Balkema, Rotterdam, p 213-223

Vicente VP (1991) Overgrowth activity by the encrusting sponge Chondrilla nucula on a coral reef in Puerto Rico. In: Ruetzler K (ed) New perspectives in sponge biology. Smithsonian Inst Press, Washington, DC, p 436-442

Wiedenmayer F (1977) Shallow-water sponges of the western Bahamas. Experientia Suppl 28, Birkhäuser Verlag, Stuttgart

Wulff JL (1997) Mutualisms among species of coral reef sponges. Ecology 78:146-159

Wulff JL, Buss LW (1979) Do sponges help hold coral reefs together? Nature 281:474-475

Zar JH (1996) Biostatistical analysis, 3rd edn. Prentice-Hall, Upper Saddle River, NJ

Zea S (1987) Esponjas del Caribe Colombiano. Editorial Catalogo Cientifico, Santa Marta, Colombia

Submitted: February 14, 2005; Accepted: July 28, 2005

Proofs received from author(s): October 15, 2005 